\title{
ANTECEDENTS OF WORK ENGAGEMENT OF HIGHER EDUCATION PROFESSORS IN BRAZIL
}

\author{
GABRIELE D. MERCALI ${ }^{1}$ \\ (iD) https://orcid.org/0000-0002-9474-315X \\ SILVIA G. COSTA ${ }^{1}$ \\ (iD) https://orcid.org/0000-0002-4842-2654
}

To cite this paper: Mercali, G. D., \& Costa, S. G. (2019). Antecedents of work engagement of higher education professors in Brazil. Revista de Administração Mackenzie, 20(1). doi:10.1590/16786971/eRAMG190081

Submission: Abr. 30, 2018. Acceptance: July 16, 2018.

Universidade Federal do Rio Grande do Sul (UFRGS), Porto Alegre, RS, Brazil.

\section{(cc) BY




\section{ABSTRACT}

Purpose: This research aimed to identify and analyze the antecedents of work engagement through job demands and resources of the higher education professors in Brazil.

Originality/value: First findings of engagement, job resources and demands regarding Brazilian professors sample. This dissertation contributes to the reflection of their situation and the conditions of their jobs.

Design/methodology/approach: This study used a quantitative approach by means of applying an online questionnaire composed of identification questions and two scales. The sample comprised 506 professors belonging to all federative units of the country. Data collected from the questionnaire was analyzed through descriptive statistics, analysis of variance and t-test.

Findings: The main findings show that professors, in general, have medium levels of engagement, but it is very close to the limit that can affect their health. The qualitative demands are the most expressive in the working life of these professionals and the work resources (task execution) were those that obtained the highest average among all resources, followed by the social ones. In general, professors from private institutions perceive job demands and resources more favorably than those who work in public institutions.

\section{KEYWORDS}

Engagement. Demands. Resources. Labor. Positive Psychology. 


\section{INTRODUCTION}

Work engagement, from the perspective of Positive Psychology, can generate or increase the well-being of individuals at work (Schaufeli, Dijkstra, \& Vazquez, 2013). It is considered a positive and intense state, which involves feelings of inspiration, well-being and authentic pleasure (Magnan, Vazquez, Pacico, \& Hutz, 2016; Bakker, Demerouti, \& Sanz-Vergel, 2014). Thus, considering that a large part of the day is spent in the work routine, the better the individual's perception of the meaning of work, the greater is their engagement in it.

Engagement emerges as a topic at the beginning of the 21 st century and is related to two converging events: the growing importance given to human capital and to the psychological involvement of employees with the business; and increased scientific interest in positive psychological states (Schaufeli, 2014). The relevance of addressing this topic to professional practice lies in the fact that engaged individuals are described as essential to organizational success and efficiency (Luthans \& Youssef, 2007; Schaufeli, 2014; Schaufeli et al., 2013). A set of changes related to the process of transition from traditional to modern organizations gains prominence in the work sphere, and therefore the concept of engagement acquires more and more visibility (Schaufeli, 2014). In the individual domain, this construct arises by characterizing people who seek to balance work in a positive way in terms of physical and mental health and also seek pleasure in the performance of the tasks of their work routine (Schaufeli et al., 2013).

The objective of this study is to identify and analyze the main antecedents, the external job demands, and resources related to the work engagement of Brazilian higher education professors, as well as to analyze whether there are differences between public and private institutions for these elements. This study is part of a master's degree project, therefore, there are different developments based on findings from the same sample.

Regarding the target audience of this study, it is well known that researches with professors in Brazil are strongly linked to studies on burnout (Carlotto \& Palazzo, 2006) and stress (Dalagasperina \& Monteiro, 2016). No studies addressing in depth the topic of engagement from the perspective of the Positive Psychology movement, for professors throughout Brazil, were found.

This research encompasses higher education professors in Brazil, by including professionals from all of the country's federative units, from federal, state and private institutions. A survey from the National Institute 
for Educational Studies and Research "Anísio Teixeira" (INEP, 2016) shows that there is a total of 397,611 professors in the country and that, overall, the number of professors with master's degrees is greater, followed by doctoral degrees, and then by postgraduate specialization degrees. In both federal and state public institutions, the number of professors with doctor's degrees is higher. In private institutions, it is evidenced that professors with master's degree are more than twice the number of professors with doctorate degrees, and there is a significant number of specialization degree holders as well as.

Regarding the work regime of Brazilian professors, the majority of professors is included in the full-time regime. Public institutions have most professors in this regime, whereas private institutions have more homogeneous distribution in the three types of work regime, with a larger amount of part-time employees, followed by hourly employees. In total, the country has more male professors in all administrative division categories (federal, state and private). Next, the work engagement theory will be clarified for a better understanding of the results found.

\subsection{Work Engagement}

This research is based on the concept of work engagement related to the Positive Psychology movement, by approaching the antithesis to burnout in the theory of Schaufeli, Salanova, González-Romá, and Bakker (2002). In Schaufeli's view (2014), although many theoretical approaches have been developed to explain the psychological mechanisms underlying work engagement, the job demands-resources model is the one with the most solid empirical foundations to date.

The theoretical model called Job Demands-Resources (JDR) suggests the evaluation and interpretation of positive characteristics in the work environment and not only elements linked to people's illness. These two aspects together illustrate the causes and consequences of work engagement (Magnan et al., 2016). This theory works with the two categories that organize the characteristics of jobs: demands and resources. They are regarded as initiators of the straining process and the motivational process, for they can be observed in essentially all types of jobs and have a joint and interactive effect on the employees' well-being (Bakker \& Demerouti, 2014).

This model includes two different psychological processes that play a role in the development of job strain and motivation. It assumes that strain can be caused by high levels of demands and low levels of resources at work, 
which are, however, linked to multiple indicators and not limited to burnout indicators (Taris \& Schaufeli, 2016). The straining process includes poorly designed positions and chronic job demands, which lead to employees' physical and mental exhaustion and may consequently lead to energy depletion and health problems. The second process proposed by the model is the motivational one, which assumes that job resources have the potential to motivate and lead to a state of high work engagement, low depersonalization, and excellent performance. These resources can play an intrinsic motivational role, since they are responsible for personal growth, learning, and development of employees and also an extrinsic motivational role, as they are functional in the achievement of work goals (Bakker \& Demerouti, 2007).

An in-depth revision of the model was carried out by Bakker and Demerouti (2007). Their main contribution was the idea that the job resources and demands can interact, which affects the strain and motivation processes. In addition, the authors found that the interaction of different types of demands and resources can predict job strain. Thus, although the main effects of demands and resources on strain and motivation are interpreted by two separate processes, this does not apply to their interaction, on which a variety of explanations can be raised (Taris \& Schaufeli, 2016).

Engagement can, therefore, be characterized by an optimal and healthy functioning of dynamic balancing between job demands and resources (Bakker \& Demerouti, 2007). Associating job demands with adequate resources causes people to challenge themselves to engage in concrete and more difficult professional activities, giving them more pleasure when performing them. Likewise, the greater the demands and the scarcer the resources, the greater the chance of illness and strain for employees (Schaufeli et al., 2002).

Given that the engagement occurs through the dynamics of the antecedents - demands and resources - the concept of engagement for Schaufeli et al. (2002, p. 74) are defined as follows:

[...] engagement is defined as a positive, fulfilling, work-related state of mind that is characterized by vigor, dedication, and absorption. Rather than a momentary and specific state, engagement refers to a more persistent and pervasive affective-cognitive state that is not focused on any particular object, event, individual, or behavior.

Vigor, dedication, and absorption (also called concentration) are, hence, three measurable dimensions that pertain to the concept of engagement. 
Vigor is understood as high energy and mental resilience levels in the workplace, persistence in difficult situations. Dedication is characterized by a sense of meaning, enthusiasm, inspiration, pride, and challenge; individuals demonstrate that they care about what happens in their daily work routines. Absorption, on the other hand, refers to concentration, immersion and focus on the job; it relates to people who consider challenge and pleasure essential in their activities (Schaufeli et al., 2002; Schaufeli et al., 2013). It is important to make clear that not feeling exhausted at work does not directly mean being involved with it since engagement and burnout can occur together up to a certain point (Schaufeli \& Salanova, 2011).

\subsubsection{Job demands and resources}

According to Bakker and Demerouti (2007), demands refer to the physical, psychological, social or organizational aspects of the job that require physical and/or psychological efforts or abilities. Some examples of it are high pressure at work, unfavorable physical environment, and emotional demand in interactions with clients. People may see the demands within organizations as negative when such demands are either disproportionate or to a high degree and meeting them requires a great amount of effort from the employee from which they are not able to recover (Meijman \& Mulder, 1998). However, they can also be seen either in a "neutral" way or as positive challenges, whose performance gives pleasure more intensely when coupled with adequate job resources (Schaufeli et al., 2013).

Resources are not only necessary to deal with the demands, they alone are important for the working life and provide energy and psychosocial support to individuals. They refer to the physical, psychological, social or organizational aspects of the job which can: be functional in achieving goals; reduce job demands and associated physiological and psychological costs; and stimulate personal growth, learning, and development (Demerouti, Bakker, \& Schaufeli, 2001). Some examples of job resources are feedback, job control, social support, opportunities for self-development in the workplace, participation in training, career opportunity, and level of autonomy (Schaufeli et al., 2013).

According to Schaufeli (2015), job demands and resources can be classified. To better understand them, their groups and some of their characteristics are presented as follows:

1. qualitative demands: concern emotional and mental demands, job interference in personal life and physical demand; 
2. quantitative demands: relate to work overload and under load and to the pace of changes in organizations;

3. organizational demands: are linked to topics such as bureaucracy, workplace harassment, role conflict, interpersonal conflicts, and organizational changes;

4. social resources: include social support from co-workers and supervisors, team climate and effectiveness, clarity of the role performed, fulfillment of expectations, and recognition of employees;

5. work resources: are associated with job control, participation in the decision-making, individuals' suitability for the job, a variety of tasks, use of employees' skills, and availability of tools;

6. organizational resources: relate to topics such as communication in the organization, alignment, and congruence of values, trust in leadership, organizational justice, and pay fairness;

7. development resources: cover topics such as performance feedback, career prospect, and the possibility of learning and development.

Initially, the JDR versions only took into account workplace characteristics. However, since most psychological approaches assume that human behavior results from an interaction between environmental and personal factors, personal resources become part of the model (Schaufeli \& Taris, 2014). These resources consist of personality characteristics such as optimism, selfconfidence or resistance to stress (Schaufeli et al., 2013). In this study, research efforts focused only on external job demands and resources. The most significant demands and resources for the researched category will be described and analyzed in results and discussion section by aiming at achieving the objective of the study.

\section{METHODOLOGY}

The objective of this research involves a quantitative approach, by using an online questionnaire composed of two scales and participants identification. This is exploratory, descriptive research, as no studies that deeply address the topic of engagement from the perspective of the Positive Psychology movement, for the target audience of professors from all over Brazil, was evidenced. Thus, we chose not to propose hypotheses in this first phase of research. 


\subsection{Participants}

The sample of this research included 506 respondent professors from all the federative units of Brazil. Figure 2.1.1 summarizes the main data of the sample characterization.

\section{(Figure 2.1.1)}

ABSOLUTE FREQUENCIES (N), PERCENTAGE (\%), MEANS AND STANDARD DEVIATIONS (SD) OF THE SOCIODEMOGRAPHIC AND JOB CHARACTERISTICS OF BRAZILIAN PROFESSORS

\begin{tabular}{|c|c|c|c|}
\hline Variables & Specifications & N (Percentage) & Mean/SD \\
\hline \multirow{2}{*}{ Sex } & Female & $260(51.4 \%)$ & \\
\hline & Male & $239(47.2 \%)$ & \\
\hline Age & & & 46.81 years old \pm 10.71 \\
\hline \multirow{2}{*}{ Marital Status } & Single & 91 (18.0\%) & \\
\hline & Married & $340(67.2 \%)$ & \\
\hline Number of Children & & & 1.8 children \pm 0.76 \\
\hline \multirow{4}{*}{ Work Regime } & Exclusive employment & 300 (59.2\%) & \\
\hline & 40 hours per week & 91 (18.0\%) & \\
\hline & 20 hours per week & $34(6.7 \%)$ & \\
\hline & Hourly rate employee & $60(11.9 \%)$ & \\
\hline \multirow{5}{*}{ Region of Brazil } & South & $248(49.0 \%)$ & \\
\hline & Southeast & $91(18.0 \%)$ & \\
\hline & Center-West & $42(8.2 \%)$ & \\
\hline & Northeast & $67(13.3 \%)$ & \\
\hline & North & $42(8.3 \%)$ & \\
\hline \multirow{3}{*}{ CAPES* Broad Areas } & Humanities & $234(46.2 \%)$ & \\
\hline & $\begin{array}{l}\text { Exact, Technological and } \\
\text { Multidisciplinary Sciences }\end{array}$ & $108(21.4 \%)$ & \\
\hline & Natural Sciences & $133(26.3 \%)$ & \\
\hline
\end{tabular}

* Capes standards for coordination for the improvement of higher education personnel. 
Regarding the type of institution, $56.9 \%$ of the participants work in federal institutions, $35.8 \%$ in private institutions, and only $4.5 \%$ in state institutions currently. Considering the total number of 397,611 professors in Brazil, according to Inep (2016), there is a probabilistic sample from a finite universe composed of 506 professionals, with a $4.3 \%$ margin of error at a $95 \%$ confidence level.

\subsection{Instruments}

The scales used as part of this research are described below. The first one has already been validated for use in Brazil, and the second one, still in process of validation, was adjusted for its better understanding during the research.

\subsubsection{Utrecht Work Engagement Scale}

The adaptation and validation of the scale for use with adults in Brazil was performed by Vazquez, Magnan, Pacico, Hutz, and Schaufeli (2015). This version has been proved to be viable for interpretation through the general score and also through the differentiation of the three dimensions (Vazquez et al., 2015). The Brazilian version demonstrated internal consistency of 0.95 for the overall work engagement factor, 0.86 for vigor, 0.87 for dedication; and 0.85 for concentration (Magnan et al., 2016).

The instrument for use in the country has 17 items, answered according to a seven-point Likert scale, being 0 for "never" and 6 for "always". Significant correlations between work engagement and work age were found in the process of adaptation and validation of the scale (Vazquez et al., 2015). Thus, age groups were associated with the career stages, being 18 to 28 years of age for the beginning of working life, 29 to 39 years of age for professional development and qualification, and over 40 years of age for career consolidation (Magnan et al., 2016).

\subsubsection{Job Demands and Resources Scale}

Topics related to job resources and demands are in process of validation by the research group coordinated by Professor Ana Claudia Souza Vazquez from the Federal University of Health Sciences of Porto Alegre (UFCSPA). The statements fall under subgroups within the Job Demands and Job Resources groups and are answered based on a seven-point Likert scale, with 0 for "never" and 6 for "always". 
Some statements have been added to the existing question basis ${ }^{2}$. Items on physical conditions of the workplace, learning, and reasoning, as well as social demands, were incorporated into the qualitative demands subgroup. In the quantitative demands section, a statement on overwork was also added. Statements about formalism, hierarchy, and organizational culture were added to the organizational demands subgroup in the scale that was used. In the job resources group, words have been modified only to facilitate the comprehension by the respondents.

The final scale has 44 statements in total. It measures the degree of frequency of statements regarding how the participant feels about their job. The raw score is obtained by means of the professors' answers for each statement and may also be calculated by subgroups.

\subsection{Procedures}

The data were collected through an online questionnaire on the online survey platform. The survey web link was sent via e-mail, and Facebook's survey tool was also used to replicate the invitation to some professors. As a form of reinforcement, telephone calls were made to the departments/ institutes/schools within the universities. In addition, the faculty contact information available on the websites of those institutions served as the primary form to search the target audience for the study. The Center for Studies and Research in Administration (CEPA) of the Federal University of Rio Grande do Sul (UFRGS) also assisted in the data collection process.

The questionnaire composed of the scales used in the research was submitted to a verbal comprehension pre-test and a statistical pre-test. The result achieved was essential for adjustments in the writing of some questions included in the scale that has not been validated for use in Brazil yet.

A balanced distribution of the questionnaire among federal, private and state universities and institutes was sought. However, in some states, mainly in the northeast and north, access to professors of private institutions was hampered by the lack of clarity of information on the websites. In the Central-West region, it was also difficult to obtain a response from professors from all the three types of institutions.

Regarding ethical procedures, the respondents obtained information about the research topic through a presentation of its objectives and the

The instrument under discussion can be found in Wilmar Schaufeli's article "Engaging leadership in the job demands-resources model" (2015). The sources of the questionnaires that compose the instrument are found in this article. 
importance of their participation for the academic community. The confidentiality of the responses and the privacy of the participants, as well as the use of the data for a global analysis, were emphasized.

\subsection{Data Analysis}

Analyzes involving descriptive statistics were made for the questions of profile identification and the results of the scales. The level of engagement through the raw and percentage scores according to the normative studies (Magnan et al., 2016) and the more frequent job resources and demands in the routine of the participants were identified.

The one-way analysis of variance (ANOVA) was used to compare the level of engagement among the working age groups. Factorial ANOVA was used to compare the engagement between types of institutions, taking into account the working age groups. Another statistical analysis performed throughout the study was the t-test for independent samples, which are, in this case, the resources and demands for groups of professors from the public and private institutions.

\section{RESULTS}

\subsection{Work Engagement for Brazilian Professors}

The Utrecht Work Engagement Scale (Vazquez et al., 2015) for this study has Cronbach's alpha of 0.942, which evidences good internal reliability of the scale for the sample of professors. Figure 3.1.1 shows the means and standard deviations calculated for each item of the scale, for each dimension, as well as the values for overall engagement.

Overall, the professors had a higher mean in the dedication dimension $(\mathrm{M}=5.21, \mathrm{SD}= \pm 0.829)$, followed by concentration $(\mathrm{M}=4.88, \mathrm{SD}= \pm$ $0.832)$ and then vigor $(M=4.77, S D= \pm 0.854)$. The most prominent items are "I am proud of the work I do" $(\mathrm{M}=5.49)$ and "I consider my work full of meaning and purpose" ( $M=5.20)$, within the dedication dimension. The statements with the lowest means are "It is difficult to disconnect from my work" $(M=4.28)$, from the concentration dimension, and "In my work, I feel I am full of energy" ( $M=4.61)$, from the vigor dimension. For the overall work, engagement construct the mean is 4.94 and the standard deviation is \pm 0.781 . 
(Figure 3.1.1)

MEANS AND STANDARD DEVIATIONS FOR ITEMS, DIMENSIONS AND OVERALL WORK ENGAGEMENT OF BRAZILIAN PROFESSOR

\begin{tabular}{|c|c|c|c|}
\hline Dimension & Items & Mean & SD \\
\hline \multirow{6}{*}{ Dedication } & I consider my job full of meaning and purpose. & 5.20 & 0.962 \\
\hline & I am enthusiastic about my work. & 5.06 & 1.051 \\
\hline & My work inspires me. & 5.11 & 1.036 \\
\hline & I am proud of the work I do. & 5.49 & 0.874 \\
\hline & To me, my work is challenging. & 5.18 & 0.971 \\
\hline & Dimension & 5.21 & 0.829 \\
\hline \multirow{7}{*}{ Concentration } & Time flies while I am working. & 5.19 & 0.983 \\
\hline & When I am working, I forget everything around me. & 4.74 & 1.177 \\
\hline & I feel happy when I am intensely involved in my work. & 5.19 & 1.007 \\
\hline & I get absorbed by my work. & 5.16 & 0.946 \\
\hline & I feel so excited that I let myself go when I am working. & 4.73 & 1.191 \\
\hline & It is difficult to disconnect from my work. & 4.28 & 1.492 \\
\hline & Dimension & 4.88 & 0.832 \\
\hline \multirow{7}{*}{ Vigor } & In my workplace, I feel I am full of energy. & 4.61 & 1.044 \\
\hline & In my workplace, I feel strong and full of vigor. & 4.77 & 1.083 \\
\hline & I feel like going to work when I get up in the morning. & 4.63 & 1.278 \\
\hline & I can keep working for very long periods of times. & 5.06 & 1.082 \\
\hline & I can adapt mentally to the difficult situations in my work. & 4.69 & 1.090 \\
\hline & $\begin{array}{l}\text { Regarding my work, I am persistent even when things do } \\
\text { not work out. }\end{array}$ & 4.87 & 1.037 \\
\hline & Dimension & 4.77 & 0.854 \\
\hline Engagement & Overall mean & 4.94 & 0.781 \\
\hline
\end{tabular}

Source: Elaborated by the authors.

According to the classification of normative studies of the Utrecht Work Engagement Scale (Vazquez, Pacico, Magnan, Hutz, \& Schaufeli, 2016), there is the following distribution for the working age range: 


\section{(Figure 3.1.2) \\ DISTRIBUTION OF PARTICIPANTS ACCORDING TO THEIR WORKING-AGE RANGE}

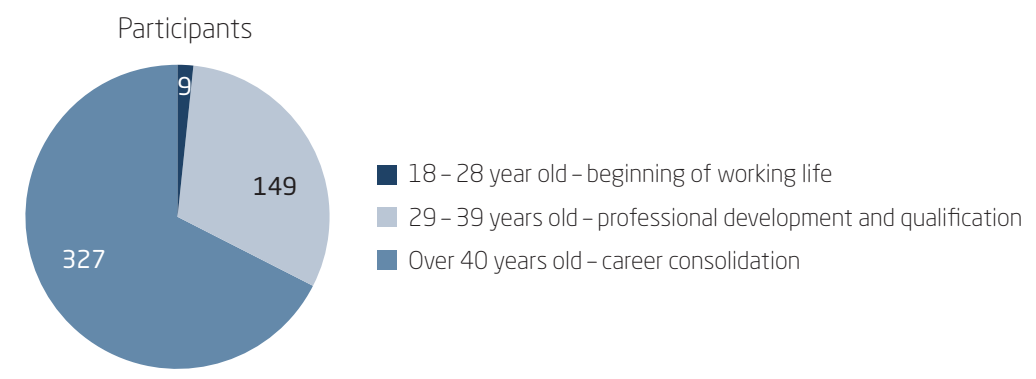

Source: Elaborated by the authors.

Considering that the distribution was not proportional, we decided to show the results of the three working-age ranges, as suggested by the normative studies, but not to make inferences about the range of 18-28 years old, which did not have the adequate representativeness. Figure 3.1.3 presents the percentiles of each dimension and the overall engagement for the working age ranges. The percentile indicates how often the score, and smaller scores, occur in the normalization sample (Hutz, 2016).

\section{(Figure 3.1.3)}

PERCENTILES OF EACH DIMENSION OF ENGAGEMENT AND OVERALL ENGAGEMENT FOR THE GROUPS OF PROFESSORS ACCORDING TO THE WORKING AGE GROUP

\begin{tabular}{lccc}
\hline \multirow{2}{*}{ Dimension } & \multicolumn{3}{c}{ Working-age range } \\
\cline { 2 - 4 } & $\begin{array}{c}\text { Percentile } \\
(18-28 \text { years old })\end{array}$ & $\begin{array}{c}\text { Percentile } \\
\text { (29-39 years old })\end{array}$ & $\begin{array}{c}\text { Percentile } \\
\text { (Over 40 years old })\end{array}$ \\
\hline Dedication & 70 and 75 & 65 & 40 \\
\hline Concentration & 75 and 80 & 60 & 55 \\
\hline Vigor & 40 and 45 & 55 & 40 \\
\hline Overall engagement & 45 & 55 & 45 \\
\hline
\end{tabular}

Source: Elaborated by the authors. 
It is well known that 75 percentiles or higher indicate high levels of engagement, greater intensity of effort and connection with work goals. Low scores are at percentiles below 40, indicating problems that may involve the workers' health. In general, median scores are expected to be found in individuals' engagement, since it is the expression of the balance of job resources and demands (Vazquez et al., 2016).

By performing the one-way analysis of variance (ANOVA), a statistically significant difference was observed among the working age groups $[\mathrm{F}(2,482)$ $=3.760 ; \mathrm{p}=0.024]$ for the engagement construct. The post-hoc test used the Bonferroni correction, which evidenced difference only between the group of 29 to 39 years old and the group of more than 40 years old ( $p=$ 0.034). The other comparisons were not significant at a $95 \%$ confidence level. The fact that the group of 18 to 28 years old had only nine people may have influenced this result.

\subsection{Job Demands and Resources for Brazilian Professors}

As the Job Demands and Resources Scale has not been validated for use in Brazil yet, calculating Crombach's alpha for the overall scale and its divisions of demands and resources was deemed necessary. Hence, we have an internal consistency of 0.918 for the overall scale, 0.771 for the demands, and 0.928 for the job resources.

When observing the means of each dimension, within the demands group, the qualitative demands obtained a higher score $(\mathrm{M}=4.01$; $\mathrm{SD}= \pm$ 0.709), followed by the quantitative demands $(M=3.00 ; S D= \pm 0.851)$ and then the organizational demands $(M=2.09 ; \mathrm{SD}= \pm 1.166)$. The statements with the highest values are part of the qualitative demands group: "My work requires constant reasoning and updating" $(M=5.57)$ and "My work requires a lot of attention and concentration" $(M=5.29)$. The item with the lowest mean is in the quantitative demands group "I have little work to do" $(\mathrm{M}=0.96)$.

Regarding resources, it was observed that the work resources related to execution and operation of tasks obtained the highest score in their means $(\mathrm{M}=4.64 ; \mathrm{SD}= \pm 0.854)$, followed by social resources $(\mathrm{M}=4.55 ; \mathrm{SD}= \pm$ $0.953)$, development resources $(\mathrm{M}=4.42 ; \mathrm{SD}= \pm 1.079)$, and organizational resources $(M=4.05 ; S D= \pm 1.120)$. The items with the highest means are "It is clear enough what I need to do in my work" $(M=5.08)$, from the social resources group, and "I perform types of tasks in my work" $(M=5.06)$, from the work resources group. The statement with the lowest mean is 
"In my opinion, the rules and procedures in my work are applied correctly and fairly" ( $M=3.52)$ from the organizational resources group.

\subsection{Demands and Resources in Public and Private Institutions}

The comparison between the types of institutions in which professors' work is very important since public institutions are subordinate to the policies defined by the Federal Government of Brazil and the State Government of each federative unit in the cases of this research, whereas the private ones do not share this situation. Due to the low number of participating professors from state institutions $(23 ; 4.5 \%)$, we decided to compute these responses together with those from federal institutions, forming the public institution's group. Thus, the private institution's group had 181 responses, and the public institution's group had 311.

When performing the Factorial ANOVA test, there was not a significant effect among types of institutions $[F(1,471)=0.407 ; p=0.524]$ for the engagement construct. There was also no significant interaction effect when taking into account the working age groups $[\mathrm{F}(2,471)=1.209 ; \mathrm{p}=0.300]$. Despite these findings, carrying out a survey on the difference in the perception of demands and resources between public and private institutions was considered relevant. Figure 3.3.1 and 3.3.2 present the items with statistically significant differences in the Job Demands and Resources Scale at a $95 \%$ confidence level when contrasting institutions.

It is worth mentioning that within the analysis of the demands the two items with the highest means for both public and private institutions were "My work requires constant reasoning and updating", with means 5.54 and 5.63, respectively, and "My work requires a lot of attention and concentration", which means 5.23 and 5.40. However, only the second item presents a statistically significant difference between institutions.

Within the demands category, when observing the difference of the means of the questions, there is a greater discrepancy in the items "The physical conditions of my workplace (light, temperature, safety, material) are adequate for the tasks I perform", followed by "I feel good about the organizational culture of the company where I work" and "I consider the implementation of changes in my work to be slow". It is worth mentioning that the first two statements are items with inverted values within the composition of the scale and were properly compensated. 


\section{(Figure 3.3.1)}

THE RESULT OF THE T-TEST FOR DIFFERENCES IN THE JOB DEMANDS BETWEEN PUBLIC AND PRIVATE INSTITUTIONS

\begin{tabular}{|c|c|c|c|c|c|}
\hline Demands & Institution & Mean & SD & $\mathrm{t}$ & $\mathrm{p}^{*}$ \\
\hline $\begin{array}{l}\text { My job requires a lot of attention and } \\
\text { concentration. }\end{array}$ & $\begin{array}{l}\text { Public } \\
\text { Private }\end{array}$ & $\begin{array}{l}5.23 \\
5.40\end{array}$ & $\begin{array}{l}0.898 \\
0.741\end{array}$ & -2.316 & 0.021 \\
\hline My job is physically demanding. & $\begin{array}{l}\text { Public } \\
\text { Private }\end{array}$ & $\begin{array}{l}3.24 \\
3.64\end{array}$ & $\begin{array}{l}1.598 \\
1.586\end{array}$ & -2.681 & 0.008 \\
\hline $\begin{array}{l}\text { The physical conditions of my workplace } \\
\text { (light, temperature, safety, material) are } \\
\text { adequate for the tasks I perform. }\end{array}$ & $\begin{array}{l}\text { Public } \\
\text { Private }\end{array}$ & $\begin{array}{l}3.60 \\
4.72\end{array}$ & $\begin{array}{l}1.687 \\
1.238\end{array}$ & -8.455 & 0.000 \\
\hline $\begin{array}{l}\text { I consider the pace of changes in my work } \\
\text { to be fast. }\end{array}$ & $\begin{array}{l}\text { Public } \\
\text { Private }\end{array}$ & $\begin{array}{l}3.02 \\
3.56\end{array}$ & $\begin{array}{l}1.586 \\
1.613\end{array}$ & -3.659 & 0.000 \\
\hline $\begin{array}{l}\text { I consider the implementation of changes in } \\
\text { my work to be slow }\end{array}$ & $\begin{array}{l}\text { Public } \\
\text { Private }\end{array}$ & $\begin{array}{l}3.51 \\
2.74\end{array}$ & $\begin{array}{l}1.786 \\
1.808\end{array}$ & -4.585 & 0.000 \\
\hline $\begin{array}{l}\text { I agree with the changes that are occurring } \\
\text { in my organization. }\end{array}$ & $\begin{array}{l}\text { Public } \\
\text { Private }\end{array}$ & $\begin{array}{l}3.28 \\
3.78\end{array}$ & $\begin{array}{l}1.415 \\
1.451\end{array}$ & -3.722 & 0.000 \\
\hline $\begin{array}{l}\text { I have been exposed to some type of moral } \\
\text { or sexual harassment in the last } 12 \text { months. }\end{array}$ & $\begin{array}{l}\text { Public } \\
\text { Private }\end{array}$ & $\begin{array}{l}1.46 \\
0.91\end{array}$ & $\begin{array}{l}2.155 \\
1.693\end{array}$ & 3.134 & 0.002 \\
\hline $\begin{array}{l}\text { There are personal conflicts among } \\
\text { members of my working team. }\end{array}$ & $\begin{array}{l}\text { Public } \\
\text { Private }\end{array}$ & $\begin{array}{l}3.08 \\
2.39\end{array}$ & $\begin{array}{l}2.129 \\
1.981\end{array}$ & 3.508 & 0.000 \\
\hline $\begin{array}{l}\text { I feel good about the organizational culture } \\
\text { of the company where I work. }\end{array}$ & $\begin{array}{l}\text { Public } \\
\text { Private }\end{array}$ & $\begin{array}{l}3.32 \\
4.17\end{array}$ & $\begin{array}{l}1.759 \\
1.532\end{array}$ & -5.570 & 0.000 \\
\hline
\end{tabular}

${ }^{*} p<0.05$.

With regard to job resources, the item with the highest mean for public institutions was "I perform different types of tasks in my work", with 5.10 and standard deviation \pm 1.190 , followed by "It is clear enough what I need to do in my work", with mean 5.01 and standard deviation \pm 1.163 . This last item had the highest score for private institutions with mean 5.18 and standard deviation \pm 0.967 , followed by "My work contributes to the results and objectives of the organization" with mean 5.09 and standard deviation \pm 1.127 . However, none of these questions showed statistically significant differences between the two types of institutions.

In the analysis of the differences between public and private institutions, the greatest difference in the means was observed in the statement "I have 
all the tools (equipment, instruments, software) I need to do my job properly", followed by "I can count on my co-workers to help me or give me support when I need" and "The management style in my institution is reliable". Overall, it can be seen that private institutions have a higher score for all resources that are statistically different, as shown in Figure 3.3.2.

(Figure 3.3.2)

THE RESULT OF T-TEST FOR DIFFERENCES IN JOB RESOURCES BETWEEN PUBLIC AND PRIVATE INSTITUTIONS

\begin{tabular}{|c|c|c|c|c|c|}
\hline Resources & Institution & Mean & SD & $\mathrm{t}$ & $p^{*}$ \\
\hline $\begin{array}{l}\text { I can count on my co-workers to help me or } \\
\text { give me support when I need. }\end{array}$ & $\begin{array}{l}\text { Public } \\
\text { Private }\end{array}$ & $\begin{array}{l}3.76 \\
4.48\end{array}$ & $\begin{array}{l}1.499 \\
1.396\end{array}$ & -5.241 & 0.000 \\
\hline $\begin{array}{l}\text { I feel my work is recognized and valued by } \\
\text { my supervisor/superior. }\end{array}$ & $\begin{array}{l}\text { Public } \\
\text { Private }\end{array}$ & $\begin{array}{l}3.87 \\
4.44\end{array}$ & $\begin{array}{l}1.714 \\
1.427\end{array}$ & -3.970 & 0.000 \\
\hline I feel it is easy to work with my team. & $\begin{array}{l}\text { Public } \\
\text { Private }\end{array}$ & $\begin{array}{l}4.17 \\
4.61\end{array}$ & $\begin{array}{l}1.368 \\
1.225\end{array}$ & -3.615 & 0.000 \\
\hline $\begin{array}{l}\text { I cooperate effectively with my working } \\
\text { team. }\end{array}$ & $\begin{array}{l}\text { Public } \\
\text { Private }\end{array}$ & $\begin{array}{l}4.83 \\
5.09\end{array}$ & $\begin{array}{l}1.153 \\
0.957\end{array}$ & -2.670 & 0.008 \\
\hline $\begin{array}{l}\text { I can deliver the work quality that is } \\
\text { expected by people in my organization. }\end{array}$ & $\begin{array}{l}\text { Public } \\
\text { Private }\end{array}$ & $\begin{array}{l}4.85 \\
5.03\end{array}$ & $\begin{array}{l}1.090 \\
0.881\end{array}$ & -1.966 & 0.050 \\
\hline $\begin{array}{l}\text { I feel recognized in my job (by co-workers, } \\
\text { citizens, students). }\end{array}$ & $\begin{array}{l}\text { Public } \\
\text { Private }\end{array}$ & $\begin{array}{l}4.32 \\
4.83\end{array}$ & $\begin{array}{l}1.436 \\
1.104\end{array}$ & -4.419 & 0.000 \\
\hline $\begin{array}{l}\text { I have all the tools (equipment, instruments, } \\
\text { software) I need to do my job properly. }\end{array}$ & $\begin{array}{l}\text { Public } \\
\text { Private }\end{array}$ & $\begin{array}{l}3.32 \\
4.44\end{array}$ & $\begin{array}{l}1.604 \\
1.468\end{array}$ & -7.683 & 0.000 \\
\hline $\begin{array}{l}\text { I am properly informed about what happens } \\
\text { in the organization. }\end{array}$ & $\begin{array}{l}\text { Public } \\
\text { Private }\end{array}$ & $\begin{array}{l}3.55 \\
3.94\end{array}$ & $\begin{array}{l}1.509 \\
1.447\end{array}$ & -2.845 & 0.005 \\
\hline $\begin{array}{l}\text { The management style in my institution is } \\
\text { reliable. }\end{array}$ & $\begin{array}{l}\text { Public } \\
\text { Private }\end{array}$ & $\begin{array}{l}3.59 \\
4.28\end{array}$ & $\begin{array}{l}1.689 \\
1.496\end{array}$ & -4.673 & 0.000 \\
\hline $\begin{array}{l}\text { In my opinion, rules and procedures in my } \\
\text { work are applied correctly and fairly. }\end{array}$ & $\begin{array}{l}\text { Public } \\
\text { Private }\end{array}$ & $\begin{array}{l}3.29 \\
3.88\end{array}$ & $\begin{array}{l}1.546 \\
1.422\end{array}$ & -4.145 & 0.000 \\
\hline $\begin{array}{l}\text { The activities as I perform are compatible } \\
\text { with my compensation. }\end{array}$ & $\begin{array}{l}\text { Public } \\
\text { Private }\end{array}$ & $\begin{array}{l}3.66 \\
4.30\end{array}$ & $\begin{array}{l}1.792 \\
1.426\end{array}$ & -4.352 & 0.000 \\
\hline $\begin{array}{l}\text { My personal values are aligned with the } \\
\text { values of the company I work for. }\end{array}$ & $\begin{array}{l}\text { Public } \\
\text { Private }\end{array}$ & $\begin{array}{l}4.14 \\
4.71\end{array}$ & $\begin{array}{l}1.512 \\
1.346\end{array}$ & -4.212 & 0.000 \\
\hline
\end{tabular}


(Figure 3.3.2 (conclusion))

THE RESULT OF T-TEST FOR DIFFERENCES IN JOB RESOURCES BETWEEN PUBLIC AND PRIVATE INSTITUTIONS

\begin{tabular}{llllll}
\multicolumn{1}{c}{ Resources } & Institution & Mean & SD & t & P* \\
\hline I receive feedback (from co-workers, & Public & 3.76 & 1.497 & & \\
students, leaders) on how I perform my job. & Private & 4.28 & 1.458 & -3.750 & 0.000 \\
\hline \multirow{2}{*}{ I always learn new things at work. } & Public & 4.86 & 1.180 & -2.124 & 0.034 \\
& Private & 5.09 & 1.112 & & \\
\hline
\end{tabular}

${ }^{*} p<0.05$

Source: Elaborated by the authors.

\section{DISCUSSION}

\subsection{Work Engagement for Brazilian Professors}

For the analysis of the reported results, considering the data in Figure 3.1.1, it can be seen that the engagement scores, taking into account the division of the working age group, are within median percentiles, as expected for the population. However, they are close to the 40th percentile, which works as a threshold value to indicate low engagement issues (Vazquez et al., 2016).

The professional development group presents more balanced percentiles in the dimensions. Dedication is in the 65th percentile, concentration is in the 60 th, and vigor is in the 55th percentile. This may represent the effort to build a career which they identify themselves with, by caring about the activities and situations that occur in the daily routine, seeing meaning in teaching students, thus ending up also being absorbed by the tasks of the occupation (Schaufeli et al., 2013). It should be noted that the vigor dimension has an increased score and may be related to a strengthening in their positions as professors, which is acquired over time.

Despite having higher means in the dimensions, the phase of career consolidation professors is, according to the normative studies, in lower percentiles when compared with the two other groups. They are in the 40th percentile for the dedication and vigor dimensions, which may demonstrate that they are under pressure by job demands or that they have few resources to be able to work properly or are not recognized as they would like to be for the activities they perform. At this stage of their working life, dedication has 
the biggest decrease, which may also be related to the fact that in the organizations they work they no longer perceive challenges to the personal resources they have developed over time (Vazquez et al., 2016). The dimension of dedication reflects enthusiasm, inspiration, and pride in the work performed (Schaufeli et al., 2002), and the possibility of professors not seeing some demands as challenges, but as a stressor, may contribute to this scenario. On the other hand, the concentration dimension, which conveys in its concept the idea that people consider challenge and pleasure in their activities to be fundamental, is in the 55 th percentile. This may suggest that, despite what was reported, these professors still feel a certain level of pleasure in carrying out tasks related to the occupation.

Thus, when observing the overall engagement, it is noticeable that the group in professional development is in a slightly better percentile than the group of career consolidation, presenting more balanced scores. Inferences were not made to the early working life group.

\subsection{Job Demands and Resources for Brazilian Professors}

The demands items with the highest mean are from the mental qualitative demands group: "My work requires constant reasoning and updating" and "My work requires a lot of attention and concentration". Rudow (1999) confirms that professors' cognitive and emotional workload can lead to chronic stress, fatigue, and burnout. This situation can lead to psychosomatic disturbances, as well as constraints to their teaching performance. Hakanen, Bakker and Schaufeli's study (2006), which is regarded as a pioneer with 2,038 elementary, secondary and vocational Finnish teachers, shows that the lack of important resources to meet the demands can further hamper work engagement and lead to a lower organizational commitment, in addition to being associated with burnout. Hence, the idea that the straining process and the motivational process are intertwined through the demands and resources dynamics is reiterated.

For the sample of Brazilian professors, most resources are found in the social and work resources groups. They reported having clarity on the roles they play, by being aware of what needs to be done in their positions. This may denote that educational institutions are structured and concerned with delimiting the roles of the faculty members as well as being sure that professors know what to do to be a professional that deals with teaching and research. Another important aspect is that they identify a variety of tasks to be performed on a day to day basis, making it difficult to be a monotonous 
or repetitive routine. Within institutions, professors can work in classrooms by teaching students, engaging in academic mentoring and projects, as well as conducting research, often working in laboratories and external fields, and even by taking up bureaucratic positions. Organizational justice appears as a low point among the resources assessed by professors, who consider that rules and procedures are not always applied correctly and fairly. Since the majority of the sample is professors in federal universities, one may think that they do not have a voice in the implementation of many regulations, having to deal with the bureaucratic logic and rigid rules (Tavares, Azevedo, \& Morais, 2014).

As far as this study is concerned, it can be seen from the means that the different resources categories are very close to each other, ranging from 4.05 to 4.64 . In the demands categories, a little more significant distance between the means can be observed, ranging from 2.09 to 4.01 . Overall, the resources obtained mean 4.42, and the demands obtained mean 3.04, thus it can be concluded that the professors in the Brazilian sample perceive more resources than demands in the work engagement process. It is worth remembering that this process is very unique, and demand can act as a resource for different people (Schaufeli et al., 2013).

\subsection{Demands and Resources in Public and Private Institutions}

As described by Rowe and Bastos (2010), the context of public and private institutions is expected to differ in terms of the conditions provided for higher education professors. The former provides professors stability and opportunity for continued education, whereas the latter does not have the stability aspect. On the other hand, there is wrecking of public universities, which face infrastructure problems in classrooms, libraries, and laboratories, as well as a lack of teaching and technical administrative staff (Sakurada, 2017). Despite the substantial differences between types of institutions, Rowe and Bastos's research (2010) revealed that their nature does not influence the professors' connection with their career regarding commitment, and such finding is in agreement with the results of this study.

The reported wrecking of the federal universities is related to the major differences between the types of institutions, which refer to the workplaces physical conditions and the tools available for the proper performance of the teaching activity. The items covering organizational culture, management of institutions, including the pace of change, may be related to the bureaucratic model found in public institutions, directly linked to Federal and State 
Governments, in which there are formal protocols that do not allow the questioning of some established norms (Tavares et al., 2014). In Carmo, Fleck and Santos' work (2015), professors reported that the nature of the public institution requires an entire bureaucratic organization to fulfill and legitimate the work routine activities, and the dysfunctions of such bureaucracy end up causing many processes to be time-consuming. In addition, professors coexist with an impersonal and institutional treatment, usually in large institutions, which generates a separation between the servant and the actual decision-makers, resulting in an exaggerated formalization of communications and difficulty to understand some procedures.

The perception of resources is favorable to professors of private institutions in this study. It should be noted that they are often hired in an hourly rate regime, which makes it possible for them to teach in various institutions. According to Scremin and Isaia (2012), this makes the professor, in some cases, become a mere "task performer" who does not have time to reflect on their teaching practice and working conditions. This situation may also explain why professors of private institutions, who commute to different locations, say they have a more physically demanding job than professors of public institutions.

Another highlight among the types of institutions is the social support from co-workers. Professors that work in private institutions demonstrate greater support and help from co-workers. It is well known that social support plays an important role in reducing the negative effects of diseases such as stress, which is evidenced in professors' lives, for social support helps in the development and promotion of coping strategies (Nurullah, 2012). When conducting a study on the perception of social support and well-being with 209 elementary school teachers, Ferraz (2009) pointed out that satisfaction with co-workers and superiors, as well as satisfaction with the task they perform, generate well-being in those teachers' lives. This state seems to be a direct consequence of the perception of the emotional support they receive on a daily basis. Thus, it is important to investigate the reason why professors of public institutions feel less social support from colleagues in their jobs, given the impact of this factor in their well-being.

To finish the discussion stage, the contributions made to the theory of work engagement and the respective demands and resources that make up its JDR model for the public of higher education professors can be mentioned. Being aware of the factors related to this positive state in professors is also deemed relevant, and not only the topics involving the study of pathologies such as stress and burnout. In addition, the dimension that may be impacting 
more dramatically - vigor - was found to be preventing professors from reaching better levels of engagement, therefore harming the well-being and perception of their performance at work. Thus, actions to provide adequate resources to the demands issues faced by professors of public and private institutions could be devised. An example would be interventions that help them increase their energy at work by acknowledging the activities performed, that is, the positive perception of the connection between their efforts and the task requested (Vazquez et al., 2016).

\section{FINAL CONSIDERATIONS}

The search for understanding the actual work situation of higher education professors is of paramount importance, given the relevance of what they are determined to accomplish in society.

Although it is widely known that the future of a nation passes through the hands of good teachers, these professionals have been experiencing moments of crisis and devaluation of their careers.

With the development of this research, it is possible to increase the awareness of the situation of these professionals, their perception not only of engagement but of all the reported elements that make up this process. Through the understanding that the engagement level of professors is considered median, but very close to a limit that would be harmful to mental health, it is possible and necessary to design interventions to support the development and improvement of the figures found. Actions that directly impact the strength of professors by increasing their energy can make a big difference in the improvement of this positive state and, consequently, the meaning of work to them.

In addition, an advance regarding the identification of professors' job demands and resources linked to engagement is noted, as this is the first study to measure these factors. Hence, we understand that a step has been taken to make it possible to compare the results with international researches on the same topic and to develop further studies in the future.

We are aware that for this study it would be interesting to obtain a closer number of respondents from each region of the country, as well as access to younger professors at the beginning of working life (18 to 28 years old). It is understood that some years of studies are required to be able to teach in an educational institution, which might explain the difficulty in finding active professors who are less than 30 years old. 
For future researches, a deeper understanding of the variation of the dimensions among the working age ranges in the professors' engagement, as well as the reason why the vigor dimension is the lowest in all these ranges, are suggested. It is also recommended to investigate how these differences occur when analyzing public and private intuitions separately.

\section{ANTECEDENTES DO ENGAJAMENTO NO TRABALHO DOS DOCENTES DE ENSINO SUPERIOR NO BRASIL}

\section{$\int$ RESUMO}

Objetivo: Esta pesquisa teve como objetivo identificar e analisar os principais antecedentes, as demandas e os recursos externos de trabalho que estão relacionados com o engajamento na esfera laboral dos docentes de ensino superior brasileiros.

Originalidade/valor: Primeiros achados sobre engajamento, recursos e demandas detrabalho com docentes de uma amostra brasileira. Contribui para a reflexão da situação em que se encontram esses professores e as condições de seus trabalhos.

Design/metodologia/abordagem: Utilizou-se a abordagem quantitativa por meio de um questionário on-line composto por perguntas de identificação e duas escalas. A amostra contou com 506 professores pertencentes a todas às unidades federativas do país. Os dados coletados foram analisados por meio de estatística descritiva, análise de variância e teste $t$. Resultados: Os principais achados mostram que os docentes, de forma geral, possuem escores medianos de engajamento, porém muito próximos de um limite que pode afetar a saúde mental deles. As demandas qualitativas e os recursos de trabalho (execução de tarefas) são os mais expressivos na vida laboral desses profissionais. De modo geral, os docentes de instituições privadas percebem as demandas e os recursos de trabalho de maneira mais favorável que os que atuam em instituições públicas.

\section{PALAVRAS-CHAVE}

Engajamento. Demandas. Recursos. Trabalho. Psicologia Positiva. 


\section{REFERENCES}

Bakker, A., \& Demerouti, E. (2007). The job demands-resources model: State of the art. Journal of Managerial Psychology, 22 (3), 309-328. doi:10.1108/ 02683940710733115

Bakker, A., \& Demerouti, E. (2014). Job demands-resources theory. In P. Y. Chen, \& L. C. Cooper. Work and wellbeing: A complete reference guide (vol. 3). Chichester, UK: John Wiley \& Sons. doi:10.1002/9781118539415. wbwell019

Bakker, A., Demerouti, E., \& Sanz-Vergel. (2014). Burnout and work engagement: The JD-R approach. Annual Review of Organizational Psychology and Organizational Behavior, 1, 389-411. doi:10.1146/annurev-orgpsych031413-091235

Carlotto, M. S., \& Palazzo, L. D. S. (2006). Síndrome de burnout e fatores associados: Um estudo epidemiológico com professores. Cadernos de Saúde Pública, 22(5), 1017-1026. doi:10.1590/S0102-311X2006000500014

Carmo, K. L. F., Fleck, C. F., \& Santos, J. U. L. (2015). Docente em universidade pública ou privada? Desafios, oportunidades e diferenças. Revista de Administração IMED, 5(2), 166-180. doi:10.18256/2237-7956/ raimed.v5n2p166-180

Dalagasperina, P., \& Monteiro, J. K. (2016). Estresse e docência: Um estudo no ensino superior privado. Revista Subjetividades, 16(1), 37-51. doi:10.5020/23590777.16.1.37-51

Demerouti, E., Bakker, A., Nachreiner, F., \& Schaufeli, W. (2001). The job demands-resources model of burnout. Journal of Applied Psychology, 86, 499-512. doi:10.1037/0021-9010.86.3.499

Ferraz, C. R. A. (2009). Percepção de suporte social e bem-estar no trabalho: Um estudo com professores (Unpublished doctoral dissertation). Universidade Metodista de São Paulo, São Bernardo do Campo, SP, Brazil.

Hakanen, J. J., Bakker, A. B., \& Schaufeli, W. B. (2006). Burnout and work engagement among teachers. Journal of School Psychology, 43, 495-513. doi:10.1016/j.jsp.2005.11.001

Hutz, C. S. (Org.). (2016). Avaliação em psicologia positiva: Técnicas e medidas. Porto Alegre, RS: Artmed.

Inep (2017). Instituto Nacional de Estudos e Pesquisas Educacionais Anísio Teixeira: Sinopse estatística da educação superior 2016. Retrieved from http://portal.inep.gov.br/web/guest/sinopses-estatisticas-da-educacaosuperior 
Luthans, F., \& Youssef, C. M. (2007). Emerging positive organizational behavior. Journal of Management, 33(3), 321-349. doi:10.1177/01492063 07300814

Magnan, E. dos S., Vazquez, A. C. S., Pacico, J. C., \& Hutz, C. S. (2016). Normatização da versão brasileira da Escala Utrecht de engajamento no trabalho. Avaliação Psicológica, 15(2), 133-140. doi:10.15689/ap.2016. 1502.01

Meijman, T. F., \& Mulder, G. (1998). Psychological aspects of workload. In P. J. Drenth, H. Thierry, \& C. J. Wolff (ed.). Handbook of work and organizational psychology (2nd ed., p. 5-33). Erlbaum, UK: Hove.

Nurullah, A. S. (2012). Received and provided social support: A review of current evidence and future directions. American Journal of Health Studies, 27(3), 173-188.

Rowe, D. E. O., \& Bastos, A. V. B. (2010). Vínculos com a carreira e produção acadêmica: Comparando docentes de IES públicas e privadas. Revista de Administração Contemporânea, 14(6), 1011-1030. doi:10.1590/S1415-6555 2010000700003

Rudow, B. (1999). Stress and burnout in the teaching profession: European studies, issues, and research perspectives. In R. Vandenberghe, \& A. M. Huberman (eds.). Understanding and preventing teacher burnout: A sourcebook of international research and practice (p. 38-58). Cambridge, UK: Cambridge University Press. doi:10.1017/CBO9780511527784.004

Sakurada, P. K. C. (2017). O sucateamento da universidade pública: A realidade dos cursos de Serviço Social da UFES e UFF. Universidade e Sociedade, 59, 70-81.

Schaufeli, W. (2014). What is engagement? In Truss, C., Delbridge, R., Alfes, K., Shantz, A., \& Soane, E. (Eds.). Employee engagement in theory and practice. UK: Routledge.

Schaufeli, W. (2015). Engaging leadership in the job demands-resources model. Career Development International, 20(5), 446-463. doi:10.1108/CDI02-2015-0025

Schaufeli, W., Salanova, M., González-Romá, V., \& Bakker, A. B. (2002). The measurement of engagement and burnout: A two sample confirmatory factor analytic approach. Journal of Happiness Studies, 3, 71-92. doi:10.1023/ A:1015630930326

Schaufeli, W., Dijkstra, P., \& Vazquez, A. C. (2013). Engajamento no trabalho. São Paulo, SP: Casa do Psicólogo. 
Schaufeli, W., \& Salanova, M. (2011). Work engagement: On how to better catch a slippery concept. European Journal of Work and Organizational Psychology, 20(1), 39-46. doi:10.1080/1359432X.2010.515981

Schaufeli, W., \& Taris, T. (2014). A critical review of the job demandsresources model: Implications for improving work and health. In Bauer, G., \& Hämmig, O. (Eds.). Bridging occupational, organizational and public health (pp. 43-68). Holanda: Springer. doi: 10.1007/978-94-007-5640-3_4

Scremin, G., \& Isaia, S. M. de A. (2012). Um estudo sobre funções docentes nas universidades privadas brasileiras e indicadores de qualidade. Educação Unisinos, 16(1), 27-35. doi:10.4013/edu.2012.161.03

Taris, T., \& Schaufeli, W. (2016). The job demand-resources model. In S. Clarke, T. M. Probst, F. Guldenmund, \& J. Passmore (Eds.). The wiley blackwell handbook of the psychology of occupational safety and workplace health (pp. 157-180). Chichester, UK: John Wiley \& Sons, Ltd.

Tavares, A. M. B. N., Azevedo, M. A., \& Morais, P. S. (2014). A administração burocrática e sua repercussão na gestão escolar. HOLOS, 2. doi:10.15628/ holos.2014.2155

Vazquez, A. C. S., Magnan, E. dos S., Pacico, J. C., Hutz, C. S., \& Schaufeli, W. (2015). Adaptation and validation of the Brazilian version of the Utrecht Work Engagement Scale. Psico-USF, Bragança Paulista, 20(2), 207-217. doi:10.1590/1413-82712015200202

Vazquez, A. C. S., Pacico, J. C., Magnan, E. dos S., Hutz, C. S., \& Schaufeli, W. (2016). Avaliação do engajamento das pessoas com seu trabalho: A versão Brasileira da Escala Utrecht de Engajamento no Trabalho (UWES). In Hutz, C. S. Avaliação em psicologia positiva - técnicas e medidas. Porto Alegre, RS: Artmed.

\section{AUTHOR NOTES}

Gabriele D. Mercali, Department of Administrative Sciences, Universidade Federal do Rio Grande do Sul (UFRGS); and Silvia G. Costa, Department of Administrative Sciences, Universidade Federal do Rio Grande do Sul (UFRGS).

Gabriele D. Mercali is now Ph.D. Student at School of Management at Universidade Federal do Rio Grande do Sul (UFRGS); and Silvia G. da Costa is now Professor at Department of Administrative Sciences at Universidade Federal do Rio Grande do Sul (UFRGS).

Correspondence concerning this article should be addressed to Gabriele D. Mercali at Rua Washington Luiz, 855, Centro Histórico, Porto Alegre, RS, Brazil, CEP: 90010-460.

E-mail: gabi_mercali@hotmail.com 


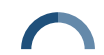

Antecedents of work engagement of higher education professors in Brazil

\section{EDITORIAL BOARD}

Editors-in-chief Janette Brunstein

Silvio Popadiuk

Associated Editor

Andrea Oltramari

Technical Support

Vitória Batista Santos Silva

\section{EDITORIAL PRODUCTION}

Publishing Coordination Irina Migliari

Layout Designer

Emap

\section{Copyeditor}

Irina Migliari (English)

Graphic Designer

Carlos Villarruel (Portuguese)

\section{Language Editor}

Daniel de Almeida Leão (English)

Irina Migliari (Portuguese) 